\title{
TEACHING VALUES THROUGH STORIES WITH MORALS
}

Гончар О. М. Виховання моральних цінностей у студентів на основі оповідань англомовних письменників.

Стаття демонструє використання на заняттях 3 аналітичного читання оповідань відомих англійських i американських письменників задля того, щоб прищеплювати високі моральні цінності та розширити світогляд студентів.

Ключові слова: цінності, ціннісна система особистості, англійська та американська художня література, заняття з аналітичного читання.

Гончар Е. Н. Воспитание моральных ценностей у студентов на основе рассказов англоязычных писателей.

Статья показывает, как преподаватель английского языка может использовать рассказы известных английских и американских писателей, чтобы привить студентам высокие моральные ценности и расширить их кругозор.

Ключевые слова: привитие ценностей, ценностная система личности, занятие по аналитическому чтению.

Honchar O. M. Teaching values through stories with morals.

The article is an attempt to illustrate how the English language teacher can use stories of English or American writers to inculcate high moral values, broaden student's mind and alleviate prejudices.

Key words: inculcation of values, value-based text, literary works, integrity

Inculcation of values through language teaching is a great challenge for a language teacher. Generally, people learn a language for communication. They learn a second language for communication. They learn a second language especially English for upward social mobility, to get better job and for higher socio economic status. The second language, which is an additional accomplishment, is related with their mind, intellect and understanding and not with their spirit, heart, feelings. But it is a language, which connects one person with others and helps him know about others' views, ideas and outlook. Thus, it broadens one's mind, alleviates prejudices, widens outlook and brings people closer.

Language teachers can successfully inculcate various values through their sessions. Language teaching has an infinite capacity for assimilating value education. Language cannot be taught in isolation, away from social situation, nor can values be imbibed without practice. Mingling good meaningful value - based text with language learning can invariably make sensitive human beings and conscientious citizens.

Language is a great house of good stories. These stories often 
provide good moral values. Through these delightful, entertaining and purposeful stories, great moral values can be inculcated.

Teaching values through stories with morals or lessons: Another way of approaching morals, values, and worldviews is through stories and examples that speak directly to particular values. A story is told with a lesson embedded in it. Typically, the stories show how to behave or how not to obey in situations where a decision has to be made. Often in these stories right behaviors and actions are rewarded and, of course, wrong behaviors bring undesirable consequences.

Fables and parables have been used to teach right and wrong for thousands of years. This approach is most effective when the listener or reader is provoked to think by the story and then through discussion and thought discovers the lesson embedded in the story. Obviously, the lesson in the story can be too difficult to figure out or too obvious. When either is true, the approach is not very successful. It also fails if a lesson runs contrary to the existing worldview of the audience and when the story seems to be an attempt to force a belief that they do not want to accept. The story approach offers a lot of possibilities for the teacher. Most importantly, stories have plots, characters, and settings - all factors that make them both interesting to listen to or read and, at the same time, memorable.

Nonfiction or fiction stories provide a way to look at different cultures, different times, and different beliefs. Every folk story tells a great deal about the culture from which it came. It shows what those people believed and, more importantly, what they thought was worth teaching or passing along to the younger generation.

Stories offer opportunity for discussion and thinking, for questions, for focusing on alternatives, and for comparison both with other stories and with personal experiences. Students can learn through dramatizing experiences with stories, through looking at character motivation, through examining alternative outcomes and beginnings, and through looking at the author's viewpoint, for example.

In Langston Hughes «Thank You M'am'», he uses conflict and imagery to express the theme of giving and understanding by showing compassion.

It is a classic story that shows that sometimes giving a hand up is more important than anything else.

Hughes expertly weaves these two characters together in this moment in time. The wise beneficent older woman and the troubled boy who would steal for what he reveals is the desire for blue suede shoes. Hughes continues to take unusual turns with the character of Mrs. Jones. One would expect her to think that the blue suede shoes weren't worth 
stealing and potentially going to jail, but Mrs. Jones has apparently in her past underwent her own transformation. She tells the boy that she too remembers a time when she wanted nice things and she couldn't afford them. What's more, she admits that she has probably done some less than moral things in the desire for nice things herself, but she wasn't going to reveal the specifics of those actions to anyone but God. In the most surprising act of the story, Mrs. Jones reaches into the same pocketbook that the boy attempted to steal and hands him a $\$ 10$ bill telling him to go buy himself some blue suede shoes. How many people would invite a thief to supper and then hand him the money he wanted to begin with? No doubt, it would be few and far between.

With all of the unexpected charity along with the assertive figurative and literal strength in the character of Mrs. Jones, Hughes creates one of the most unique and rich characters in American literature.

Below I suggest some ideas for the lesson exploring the nature of integrity based the Langston Hughes story.

\section{Lesson Procedures}

\section{Part One: Integrity}

1. Explain that in preparation for reading the story «Thank you, Ma'm» by Langston Hughes students will explore the trait of integrity. Ask the class what integrity means. Using the Latin root integer (whole or complete, as used in integral, integer, and integrate), guide the discussion to help the students include the following in their definition:

a. The quality or state of being whole, unbroken, complete.

b. Having sound moral principles.

c. Having the courage to do what is right, even if it is difficult.

d. Being honest, fair, and trustworthy.

2. Explain, if necessary, how being «whole» means not compromising values including honesty, fairness, and trustworthiness. Suggest that as a result of demonstrating integrity, respect and trust can develop.

3. Have students use a T-chart to create lists of people who show or should show integrity and a list of people who often do not show integrity.

The lists might include judges, police, parents, doctors, and religious leaders on one list, and thieves, cheaters (including cheaters on academic work) liars, criminals on the other side.

If students suggest questionable individuals such as gang members or some celebrities, ask to whom these people show integrity and to whom they do not show integrity. Ask, Is it integrity - wholeness, completeness, of sound principles - if it is shown only part of the time or in limited situations or to selected people? Does someone have integrity if they choose to be fair and 
honest only in certain circumstances? Does this make them trustworthy?

Ask what happens to society when we cannot rely on the integrity of the people in the first list (judges, police, parents, doctors, and religious leaders.) Be respectful and attentive if the students' experiences and perceptions are different than your own. They are exploring the definition and possibly struggling with the implication of integrity in their own lives as teenagers.

Alternatively, use the same procedure to list behaviors (rather than people) that show integrity and behaviors that show a lack of integrity.

4. Have students respond to these warm-up prompts: Is it more natural to have integrity, or more natural not to have integrity? What might cause people to have integrity or to lose their integrity?

5. After writing, have students pair up and share their responses. Conduct a class discussion based on their responses. They may bring up corruption, greed, poverty, and peer pressure on one side, and family, religious and ethical teachings on the other.

\section{Part Two: Reading and Responding}

6. Explain that the Langston Hughes story explores several values, including integrity, and they will explore the nature of integrity through the story.

Reading and literary analysis of the story «Thank You, M'am» by Langston Hughes according to the following scheme:

\section{Plot:}

\section{- Exposition:}

The story starts with Roger trying to steal Mrs. Jones' pocketbook, but he is caught and then gets threatened by her. She decides to take him back to her apartment instead of calling the police. Roger explains that he is in need of money to buy a pair of shoes.

- Complication (rising action): the story is introduced by a conflict when the child tries to snatch M'am purse in the road. But he failed to do it and was forced to follow M'am to her apartment.

\section{- Climax:}

«He could make a dash for it down the hall. Run, run, run, run» This is the climax in the story Thank you M'am by Langston Hughes. This climax is a special one, because of where it is placed, how it is not commonly used, and how it is used.

One of the most amazing things about this climax in the story is where it is placed. The climax for Thank You M'am is in a quiet place in the story where nothing was really going on. Roger was washing his face, and Mrs. Luella Bates Washington Jones was sitting on her bed. A lot of people would have thought that it was in the beginning when Roger and 
Mrs. Jones were fighting for the purse, but it's not, and that's what makes this climax unexpected.

- Falling action: Roger is helped by M'am

- Resolution: M'am gives him something to eat and ten dollars to get suede shoes, and the boy promises not to make mistake of latching onto M'am pocketbook nor nobody else's, so the son will behave himself.

\section{Characters:}

Both characters are the protagonists. Roger, can be viewed as a dynamic character.

- Roger: (Protagonist) tries to get suede shoes by picking pocket in a road, but he is not a strong boy. He is a simple child that can be changed for better. He doesn't want to follow M'am and his only wish is to run away from her.

- Mrs. Luella Bates Washington Jones: (protagonist) a kind woman who wants to help a little boy on the street, she gives him food from the ice box and some money to get what he wants to buy, she also gives him advice to get rid off such a bad habit as picking pockets: «You ought to be my son. I would teach you right from wrong. Least I can do right now is to wash your face. Are you hungry?»

\section{Setting:}

The setting of the short story, Thank You, M'am by Langston Hughes, takes places during the early 1900 s. There is a large woman named Mrs. Luella Bates Washington Jones and a young boy named Roger. It's about eleven o'clock at night, on the road where the woman walked alone and in the woman's house.

Theme: this story is about a poor boy who meets the kind M'am. She gets concerned about the boy's condition. She wants to help him. So the theme is kindness .Kindness is a more effective tool for rehabilitating criminal behavior than punishment, trust can build relationships in the most unexpected places, offering kindness to a bad person can have transforming results, people respond more positively to trust and kindness than to punishment.

7. After the reading and discussion have students think about and respond to this prompt or writing below their response to the initial warmup prompt: Can people improve the integrity (or trustworthiness, or fairness or honesty) of others through their own actions? Why or why not? If yes, how? If no, why not?

\section{Part Three: Making It Personal}

8. Think and write about the integrity you show through your actions, including actions at school. How do those actions affect others? What can you do to improve your own integrity and integrity of those 
around you? Include the following in your writing: Write about a time when your integrity was challenged or compromised and what you did or what you could have done differently; How has your integrity (or lack of integrity) affected the integrity of other people?

\section{Література}

1. Гужва Т. Английский язык. Тексты для чтения и аудирования : [підручник для абітурієнтів, слухачів курсів, студентів] / Т. Гужва, О. Кодалашвили Ю. Романовская. К. : Тандем, 1998. - Ч. 1. $-366 \mathrm{c.}$

2. Dr. Bharti Rathore. Beyond the Text : Values in Language Classes : [електронний pecypc] / Dr. Bharti Rathore. - Режим доступу : http://www.google.com.

Стаття надійшла до редакції 20.11.2013 р. 